\title{
Insulin Binding and Action in Antibody-Induced Diabetes in the Rat
}

\author{
W. Kemmler and H.U.Häring \\ Institut für Diabetesforschung, Munich, FRG
}

\begin{abstract}
Summary. The influence of antibody-induced insulin deficiency in rats on the insulin binding and insulin sensitivity of adipocytes was studied. Rats were injected intraperitoneally with an insulin antibody preparation; the development of hyperglycaemia was followed and the animals were sacrificed 3 and $5 \mathrm{~h}$ after antibody injection. Up to $3 \mathrm{~h}$, no significant change of insulin binding or sensitivity of the adipocytes occurred. At $5 \mathrm{~h}$, cells of antibody-treated rats showed an ap-
\end{abstract}

proximately $40 \%$ increased binding capacity compared with untreated rats. The increased binding capacity was accompanied by an approximate two-fold increased sensitivity of the insulin effect on lipogenesis from glucose in these cells.

Key words: Insulin deficiency, insulin receptor, fat cells, lipogenesis, antibody-induced diabetes mellitus, rat.
The up-regulation of the insulin receptor in the insulin deficient state was first observed in the genetically diabetic Chinese hamster [1]. Subsequently, this finding has been confirmed in different states of insulin deficiency, particularly in alloxan and streptozotocin diabetic animal models [2-7]. Another model of the insulinopaenic state, insulin-antibody induced diabetes, was studied for several reasons.

The pharmacological substances, alloxan and streptozotocin, have acute toxic side effects which might also influence receptor regulation and/or insulin action [8]. On the other hand, there is still some controversy about the correlation between insulin binding and insulin action in the insulin deficient stat. Up-regulation of the receptor has been reported not only with decreased responsiveness $[2,3,6,7]$ but also with hypersensitivity towards insulin [9] depending on the animal model and tissue observed. Finally, insulin-antibody diabetes allows the examination of the time course of up-regulation in vivo. This, to our knowledge, has not been studied so far.

\section{Materials and Methods}

Insulin antibodies were induced in guinea pigs by repeated injections of crystalline bovine insulin (a generous gift from Hoechst, Frankfurt, FRG). Blood was drawn by heart puncture. The insulin antibodies were concentrated by precipitation of the sera with cold saturated ammonium sulphate $(1: 1 ; \mathrm{v} / \mathrm{v})$ and used after dialysis against $0.15 \mathrm{~mol} / 1$ sodium chloride. Sera of guinea pigs not injected with insulin were treated identically and used for comparison. Male Wistar rats fed ad libitum (150-180 g body weight) were injected with the insulin antibody preparations in an amount sufficient to neutralize 5-10 U of insulin according to Wright [10]. The antibody-containing sera were able to neutralize $1.5-3 \mathrm{U}$ of insulin $/ \mathrm{ml}$. Control animals received the same amount of ammonium sulphate-treated guinea pig serum without insulin antibodies. After different time intervals the animals were sacrificed. Urine glucose was determined by Dextrostix (Ames, Frankfurt, FRG), ketone bodies by Acetest tablets (Ames, Frankfurt, FRG), blood glucose with the Gluco-quant test kit (Boehringer, Mannheim, FRG). Fat cells were prepared by the method of Rodbell [11]. All incubations were performed in Krebs-Ringer Hepes buffer ( $\mathrm{pH} 7.5$ ) containing $50 \mathrm{~g} / \mathrm{I}$ crystalline bovine serum albumin (Behring, Marburg, FRG).

\section{Insulin Binding}

Adipocytes, prepared from epidydimal fat pads $\left(4-6 \times 10^{5} / \mathrm{ml}\right.$, test volume $400 \mu \mathrm{l})$ were incubated with bovine ${ }^{125} \mathrm{I}$-insulin $\left(\mathrm{A}_{14}\right.$-labelled, ${ }^{125} \mathrm{I}$-insulin, specific activity $260 \mu \mathrm{Ci} / \mu \mathrm{g}$, Novo Industri, Bagsvaerd, Denmark) at a concentration of $0.33 \mathrm{nmol} / 1$ alone or together with unlabelled insulin $(0.066-6.6 \mathrm{nmol} / \mathrm{l})$. Cells from antibody-treated animals and those from untreated animals were prepared at the same time and tested simultaneously under identical conditions. After incubation for $45 \mathrm{~min}$ at $25^{\circ} \mathrm{C}$, medium and cells were separated by the oil centrifugation technique described by Gliemann et al. [12]. The tube was cut at the oil layer and the radioactivity of the cell layer was determined. To measure non-specific binding, excess unlabelled insulin $(6.6 \mathrm{mmol} / \mathrm{l})$ was added with the labelled insulin. The amount of insulin not dissociating from the cells under these conditions was considered to be non-specifically bound and subtracted from each value. This ranged from $7-13 \%$ of the total ${ }^{125} \mathrm{I}$-insulin bound in the absence of unlabelled insulin. The non-specific binding was not different in 

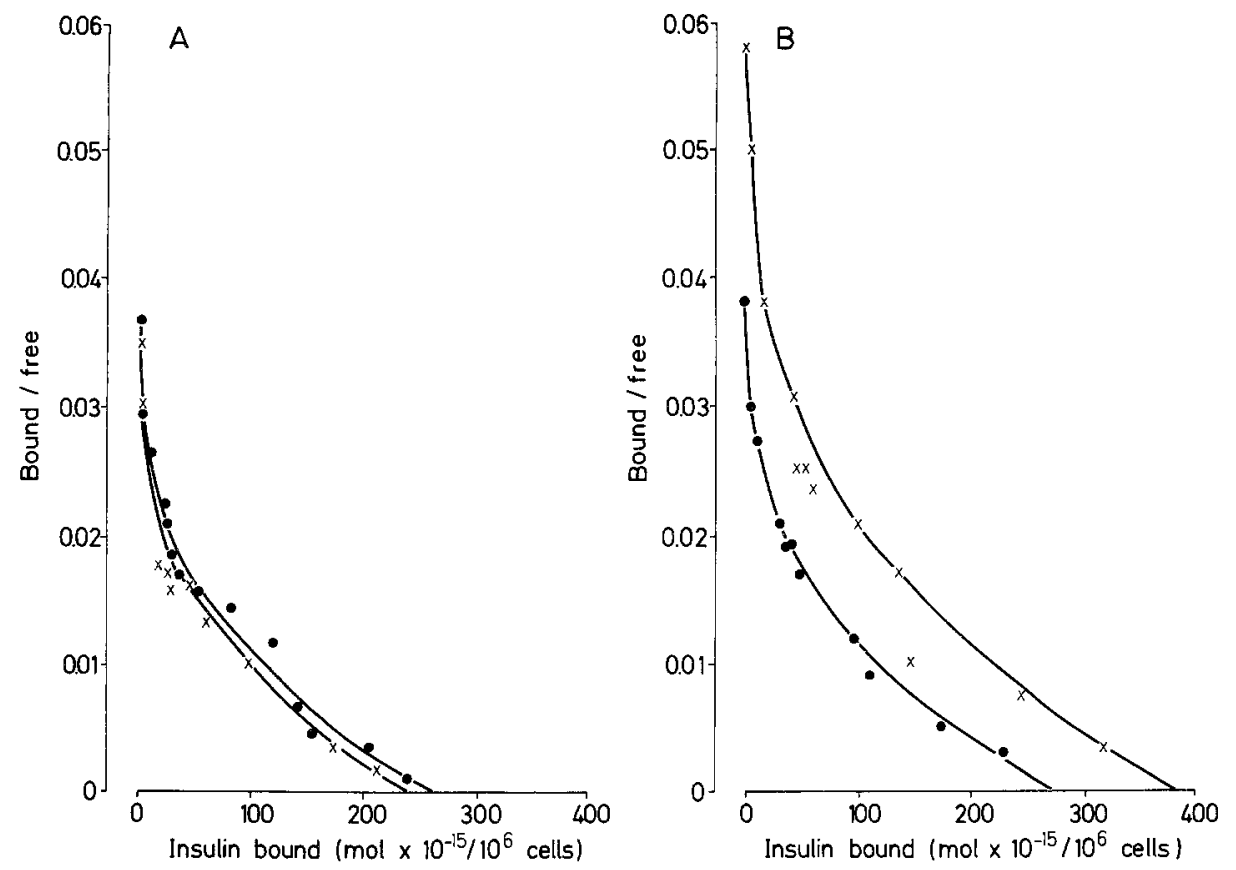

Fig. 1 A and B. Scatchard plot of insulin binding to fat cells of antibody-treated rats $(x-x)$ and untreated animals $(\bigcirc)$. A $3 \mathrm{~h}$ after injection of the antibody $(n=4)$. B $5 \mathrm{~h}$ after injection of the antibody $(n=5)$, the insulin concentrations bound are shown in Table 2

Table 1. Development of hyperglycaemia in insulin antibody-treated animals

\begin{tabular}{lll}
\hline $\begin{array}{l}\text { Time after } \\
\text { injection } \\
(\mathrm{h})\end{array}$ & $\begin{array}{l}\text { Blood glucose } \\
(\mathrm{mmol} / \mathrm{l})\end{array}$ & $\begin{array}{l}\text { Urine glucose } \\
(\mathrm{mol} / \mathrm{l})\end{array}$ \\
\hline 0 & $5.0 \pm 1.1$ & negative \\
1 & $10.8 \pm 0.8$ & traces \\
2 & $13.7 \pm 1.8$ & 0.011 \\
3 & $13.3 \pm 2.4$ & 0.03 \\
4 & $16.3 \pm 1.6$ & 0.11 \\
5 & $16.9 \pm 2.3$ & $0.11-0.27$ \\
\hline
\end{tabular}

Results are expressed as mean \pm SEM from 18 animals. Antibodycontaining sera were injected at time 0 . Blood was taken from the tail of the antibody-treated and untreated rats hourly. The blood glucose values of the untreated group did not change after injection of the sera without antibodies $(6.2 \pm 0.9 \mathrm{mmol} / 1$ at time zero and $6.4 \pm$ $1.4 \mathrm{mmol} / 1,5 \mathrm{~h}$ after injection; $n=18$ )

Table 2. Binding of insulin to fat cells of antibody-treated and untreated rats $5 \mathrm{~h}$ after injection

\begin{tabular}{lcc}
\hline $\begin{array}{l}\text { Insulin } \\
\text { concentration } \\
(\mathrm{mmol} / \mathrm{l})\end{array}$ & $\begin{array}{l}\text { Antibody-treated rats } \\
\left(\mathrm{mol} \times 10^{-5} / 10^{6} \text { cells }\right)\end{array}$ & $\begin{array}{l}\text { Untreated rats } \\
\left(\mathrm{mol} \times 10^{-5} / 10^{6} \text { cells }\right)\end{array}$ \\
\hline 0.033 & $3.6 \pm 0.5$ & $2.3 \pm 0.4$ \\
0.10 & $8.6 \pm 0.9$ & $5.5 \pm 0.7$ \\
0.20 & $16.6 \pm 2.5$ & $11.6 \pm 1.6$ \\
0.66 & $43.3 \pm 6.6$ & $30.2 \pm 4.3$ \\
0.83 & $51.6 \pm 4.6$ & $41.6 \pm 4.1$ \\
1.00 & $51.4 \pm 5.1$ & $40.0 \pm 4.5$ \\
1.33 & $55.0 \pm 5.4$ & $46.6 \pm 2.6^{\mathrm{a}}$ \\
4.00 & $136.6 \pm 6.0$ & $96.6 \pm 4.3^{\mathrm{b}}$ \\
7.33 & $146 \pm 20$ & $111 \pm 7^{\mathrm{a}}$ \\
20.66 & $248 \pm 10$ & $182 \pm 17^{\mathrm{a}}$ \\
36.60 & $331 \pm 16$ & $230 \pm 41^{\mathrm{b}}$ \\
\hline
\end{tabular}

The values represent the mean \pm SEM of five experiments. ${ }^{\mathrm{a}} p<0.05,{ }^{\mathrm{b}} p<0.025$ treated versus untreated rats. The animals studied were the same as tested for glucose in Table 1 the two groups of fat cells from antibody treated and untreated animals.

Lipogenesis from $2-\left[{ }^{3} \mathrm{H}\right]$-glucose was determined according to Moody et al. [13]. Total lipids were measured as described by Zöllner and Kirsch [14]. Statistical analyses were performed using the Wilcoxon-Wight-Whitney rank sum test.

\section{Results}

Table 1 shows the development of hyperglycaemia in the insulin antibody treated rats over the $5 \mathrm{~h}$ following injection. About one-third of the animals injected with antibodies did not develop hyperglycaemia. These rats were excluded from the experiments. None of the animals had ketonuria after $5 \mathrm{~h}$. IV injection of concentrated insulin antibodies led to inconsistant results and was therefore abandoned.

Figure 1 shows Scatchard analyses of the insulin binding of fat cells from the rats 3 and $5 \mathrm{~h}$ after injection. Table 2 shows the corresponding insulin binding to fat cells of insulin antibody treated and untreated rats after injection. After $3 \mathrm{~h}$, no significant change in the binding curves was found, whereas after $5 \mathrm{~h}$ insulin binding was increased in the antibody treated rats. The increase in binding was mainly due to the approximately $40 \%$ increase in number. The fat cell size as measured by the total lipids per cell was similar in antibody treated animals $\left(11.1 \pm 1.1 \mathrm{mg} / 10^{5}\right.$ cells $)$ and untreated animals $\left(11.3 \pm 1.3 \mathrm{mg} / 10^{5}\right.$ cells, eight determinations per group).

When insulin action on fat cell lipogenesis was studied $5 \mathrm{~h}$ after injection of the concentrated antibody-solution, a shift of the dose-response curve to the left was found in the diabetic compared with the untreated rats (Fig. 2). The basal and maximal stimulation of lipogene- 

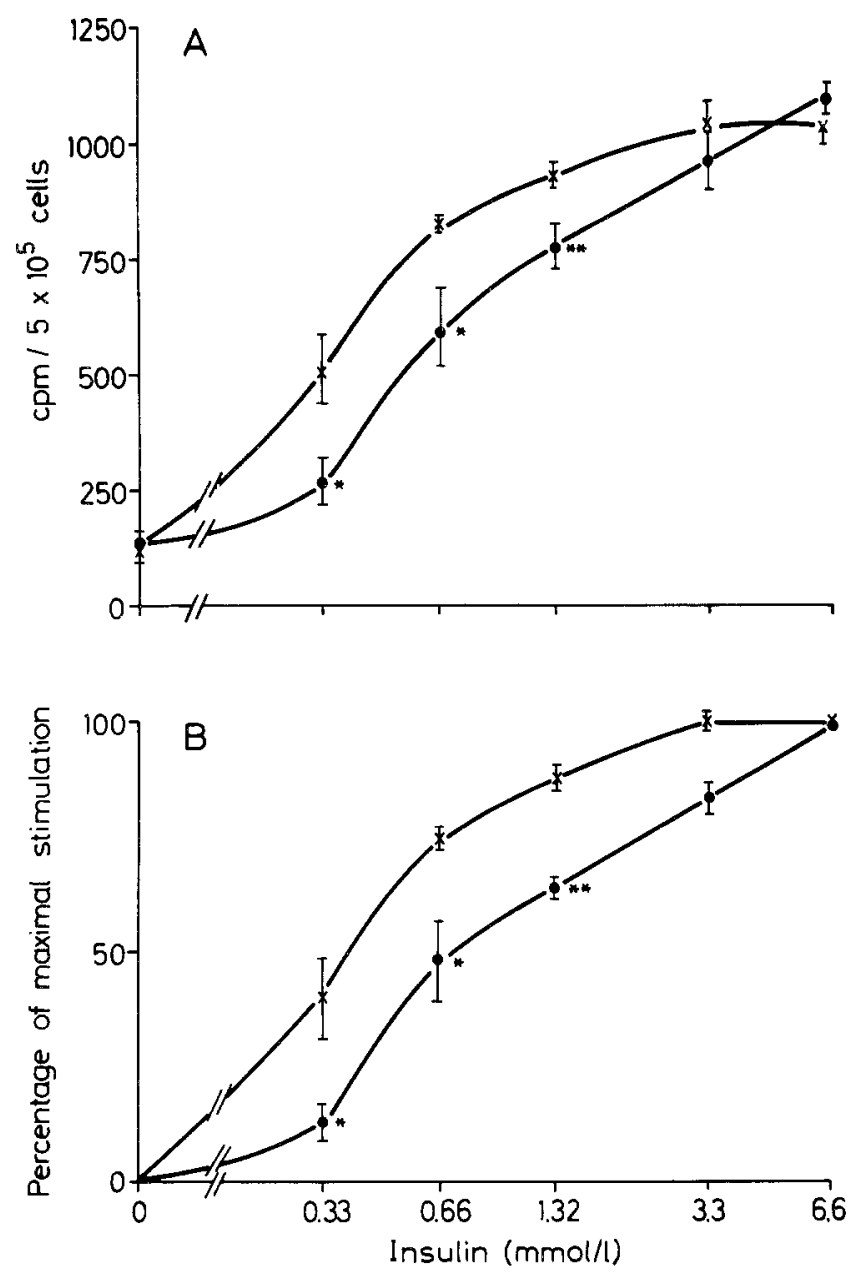

Fig. $2 \mathrm{~A}$ and B. Incorporation of $\left[{ }^{3} \mathrm{H}\right]$ from glucose into total lipids of fat cells from antibody-treated animals $(x-x)$ and untreated rats (- $5 \mathrm{~h}$ after injection. A Incorporation is expressed as cpm incorporated $5 \times 10^{5}$ cells; $\mathbf{B}$ as percentage of maximal stimulation. The values indicate the mean \pm SEM of five experiments. ${ }^{*} p<$ $0.025 ; * p<0.01$

sis were identical in both groups. To test whether the insulin antibodies themselves influenced insulin binding and action, fat cells were pre-incubated for $1 \mathrm{~h}$ with concentrated antibody solutions added to the KrebsRinger-Hepes buffer. After the washing procedure carried out during the preparation of fat cells as described by Rodbell [11], insulin binding and insulin action on lipogenesis were measured. No difference could be seen in both parameters compared with untreated cells (data not shown).

\section{Discussion}

This study demonstrates that antibody induced diabetes leads to an up-regulation of insulin binding to fat cells. The Scatchard plot suggests that this is due to an increased receptor number without a significant change in the receptor affinity. The experiments on the direct effect of insulin antibodies on fat cells showed no change in receptor binding. Thus, the inverse relationship between receptor binding and insulin levels is confirmed in another model of insulin deficiency. The advantage of the model of insulin deficiency used in this study compared with other experimental models is that the time point of the decrease of peripheral insulin levels can be relatively well defined, and it is therefore possible to study the time course of the receptor development in vivo. The up-regulation occurs in this model within $5 \mathrm{~h}$. Indirect evidence that short-term up-regulation of insulin receptors is possible has been provided by BeckNielson and Pederson [15], who showed that a 50\% variation in insulin receptor binding in human monocytes can be observed within hours. In these studies, the upregulation was, however, due to a change in receptor affinity. Down-regulation of insulin receptors, on the other hand, seems to be a faster process. Recently, Pezzino et al. [16] showed that down-regulation of rat liver plasma membranes can be induced in vivo within $10 \mathrm{~min}$ by the injection of insulin. As in our study, the change in binding was due to variation in receptor capacity and not in affinity. The up-regulation of receptors was accompanied by a shift to the left in the dose response curve of the insulin effect on lipogenesis, whereas the basal rate and the maximal effect of insulin were unchanged. Thus, as expected from an increased receptor capacity in adipocytes [17], an increased sensitivity and not an increased responsiveness was seen. Our observation that sensitivity is increased in parallel with receptor up-regulation is in contrast with reports of other models of insulin deficiency $[2,3,6,7]$. This might be a consequence of the duration of the insulin deficiency due to different kinetics of receptor regulation and of changes at the post-receptor level. Short-term insulin lack might only change the receptor while prolonged deficiency might induce additional post-receptor insulin resistance.

Acknowledgement. We thank E. Rattenhuber for her expert technical assistance.

\section{References}

1. Hepp KD, Langley J, Funcke HJ v, Renner R, Kemmler W (1975) Increased insulin binding capacity of liver membranes from diabetic Chinese hamsters. Nature 258: 154

2. Kasuga M, Akanuma Y, Iwamoto Y, Kosaka K (1978) Insulin binding and glucose metabolism in adipocytes of streptozotocindiabetic rats. Am J Physiol 235: 175-182

3. Wieringa T, Krans HMJ (1978) Reduced glucose transport and increased binding of insulin in adipocytes from diabetic and fasted rats. Biochim Biophys Acta 538: 563-570

4. Davidson MB, Kaplan SA (1977) Increased insulin binding by hepatic plasma membranes from diabetic rats. Normalization by insulin therapy. J Clin Invest 59: 22-30

5. Schoenle E, Zapf J, Froesch ER (1977) Effects of insulin and NSILA on adipocytes of normal and diabetic rats: Receptor binding, glucose transport and glucose metabolism. Diabetologia 13: 243-249

6. Kobayashi M, Olefsky JM (1979) Effects of streptozotocin-induced diabetes on insulin binding, glucose transport, and intra- 
cellular glucose metabolism in isolated rat adipocytes. Diabetes 28: $87-95$

7. Reaven GM, Sageman WS, Swenson RS (1977) Development of insulin resistance in normal dogs following alloxan-induced deficiency. Diabetologia 13: 459-462

8. Frerichs H, Creutzfeld W (1971) Der experimentelle chemische Diabetes. In: Dörzbach E (ed) Insulin, vol 1. Springer Verlag, Berlin Heidelberg New York, pp 159-202

9. Cech JM, Freeman RB, Caro JF, Amatruda JM (1980) Insulin action and binding in isolated hepatocytes from fasted, streptozotocin-diabetic and older, spontaneously obese rats. Biochem J 188: 839-845

10. Wright PH (1969) Experimental insulin deficiency due to insulin antibodies. In: Pfeiffer EF (ed) Handbook of diabetes mellitus, vol 1. JF Lehmanns Verlag, Munich, pp 841-865

11. Rodbell M (1964) Metabolism of isolated fat cells. I. Effects of hormones on glucose metabolism and lipolysis. J Biol Chem 239: $375-380$

12. Gliemann J, Osterlind K, Vinten K, Gammeltoft S (1972) A procedure for measurement of distribution spaces in isolated fat cells. Biochim Biophys Acta 286: 1-9

13. Moody AJ, Stan MA, Gliemann J (1974) A simple free fat cell assay for insulin. Horm Metab Res 6: 12-16
14. Zöllner N, Kirsch K (1962) Über die quantitative Bestimmung von Lipoiden (Mikromethode) mittels der vielen natürlichen Lipoiden (allen bekannten Plasmalipoiden) gemeinsamen Sulphovanillin Reaktion. Z Ges Exp Med 135: 545-551

15. Beck-Nielson H, Pederson O (1978) Diurnal variation in insulin binding to human monocytes. J Clin Endocrinol Metab 47: 385-390

16. Pezzino V, Vigneri R, Pliam NB, Goldfine ID (1980) Rapid regulation of plasma membrane insulin receptors. Diabetologia 19: 211-215

17. Kahn CR (1978) Insulin resistance, insulin insentivity and insulin unresponsiveness: A necessary distinction. Metabolism 27: 1893-1902

Received: 27 July 1981

and in revised form: 9 July 1982

Dr. W. Kemmler

Institut für Diabetesforschung

Kölner Platz 1

8000 München 40, FRG 